\title{
Methods of treating ruminants' diseases in veterinary hospital in Ado-Ekiti, Ekiti State
}

\author{
Bada, A. A. ${ }^{1 *}$, Adewole, S. O. $^{2}$, Olofintoye, L. K. ${ }^{2}$ and Omotoriogun T. C. ${ }^{1}$ \\ 1Department of Biological Sciences, Elizade University, Ilara-mokin, Ondo- State, Nigeria. \\ ${ }^{2}$ Department of Zoology, Ekiti State University, Ado-Ekiti, Ekiti State, Nigeria. \\ ${ }^{*}$ Corresponding author. Email: glorynew.20@gmail.com
}

Copyright () 2021 Bada et al. This article remains permanently open access under the terms of the Creative Commons Attribution License 4.0, which permits unrestricted use, distribution, and reproduction in any medium, provided the original work is properly cited.

Received 17th January, 2021; Accepted 24th February, 2021

\begin{abstract}
The aim of this study was to investigate methods of treating ruminants' diseases in Ekiti State. Information about the methods used in treating ruminants' diseases were collected from a veterinary hospital in Ado-Ekiti. Major diseases that affected the ruminants include diarrhea, mange, Peste des Petits Ruminants (PPR), mastitis, dystocia, uterine prolapse and so on. They were treated using modern drugs like; Albendazole (Leeford Health care Itd, India 1 tab), ivomec (A menarini India PVtLtd, India, $0.5 \mathrm{ml}$ ), Oxylet (Kachhela medex private limited, India, $1 \mathrm{ml}$ ), Penstrep (Dutch Farm International BV, Holland, $3 \mathrm{ml}$ ), Emvit (Uni-med, India, $2 \mathrm{ml}$ ), Oxytcin (FPP manufacturers, India, $1 \mathrm{ml}$ ), B complex (Estrellas life sciences private limited, India, $0.5 \mathrm{ml}$ ), Salphen (Industrial corporation of India, $1 \mathrm{ml}$ ) and so on. Treating the diseases of ruminants can help reduce the rate of diseases outbreak and enhance the economy value of the ruminant farmers and the that of Ekiti state at large.
\end{abstract}

Keywords: Diarrhea, diseases, economy, Ekiti State, mange, ruminant.

\section{INTRODUCTION}

Ruminants like goat, sheep and cattle were common in Ekiti state. They are also found in Africa and other countries (Wendy et al., 2015). They are affected by various pests and diseases such as mange, ticks, lice diarrhea, mastitis and helminthiasis (Adedeji and Aiyedun, 2013; Mafimisebi et al., 2012). These pests and diseases are caused by poor management practices, feeding and poor sanitation. These diseases affect the health of these ruminants and thereby causing slow growth rate and low productivity to farmers (Al-Assaf, 2012). The normal physiological functioning such as feeding, reproduction will affect the ruminants causing them to look lean and pale and hence the economic importance of the animal will be adversely affected (Wendy et al., 2015). Both traditional and modern drugs have been used to treat these pests and diseases (Yuan et al., 2016). But modern methods can provide a very reliable and effective treatment in the areas where traditional drugs cannot be used (Yuan et al.,2016). Such as in uterine prolapsed, and dystocia. The modern drug to treat diarrhea is Albendazole and mange is ivermectin (Nalule et al., 2011; Basheir et al., 2012). Penstrep (Penicillin-Streptomycin) has been used as antibiotics to treat microbial infections (Sagliyan et al., 2008).

There are various methods to treat ruminant diseases like mange, PPR, diarrhea, mastitis and dystocia. And different modern drugs have been used to treat these diseases. However, in-depth detail of drugs and methods used in treating ruminants' diseases in Ekiti State have not been fully studied. Therefore, the objective of this study is to investigate the methods used to treat ruminant diseases in Ekiti state.

\section{MATERIALS AND METHODS}

Governmental veterinary hospital located opposite the Fajuyi Park in Ado-Ekiti was visited to observe treatment diseases of ruminants and to collect information about signs and symptoms of diseases, diagnosis of diseases, 
the drugs, method of treatment and route of administration of drugs used for treating ruminant diseases. They have office, record, reception and laboratory section within the hospital.

\section{Data collection}

Information about the method of treating ruminant diseases were collected from the record section of the veterinary hospital. Also, some animals that were brought to the veterinary hospital were observed. The way the veterinary doctors and workers attend to the animals, especially goats (Capra aegarus hircus), were well observed.

Some of the drugs used for treatment were ivomec for ectoparasitic diseases, a combination of Albendazole (Leeford Healthcare Ltd, India,1 tab) and thalazole (May and Baker, Nigeria plc, 1 tab) for endoparasitic diseases such as diarrhoea, antibiotics such as penstrep (Dutch Farm International BV, Holland, $3 \mathrm{ml}$ ) to kill germs, analgesic such as salphen (Industrial corporation of India, $1 \mathrm{ml}$ ) for pain, multivitamin such as vitaflash (Kepro, Netherlands, $2 \mathrm{ml}$ ) to supply vitamins, B-complex (Estrellas Life Science private limited, India, $0.5 \mathrm{ml}$ ) to increase the appetite, oxytocin (FPP manufacturers, India, $1 \mathrm{ml}$ ) for dystocia, ivermectin (Merck sharp and Dohme pty Itd, Australia, $1 \mathrm{tab}$ ) for tapeworm treatment.

Some of the diseases treated were mange, diarrhoea, dystocia and uterine prolapsed. For dystocia, the animals were operated upon, by dissecting the left flank of the abdomen, with scissors inserted into the uterus to bring out the kids and thereafter the part of the body ligated was sutured back in place. For uterine prolapsed, the uterus was pushed back into place with a rod and the vulva was sutured leaving a small opening for excretion and reproduction. The medical devices that were used for the operation include thread, scissors needle, spirit and so on.

The various routes of administration of the drugs were intramuscular (I/M) for antibiotics and analgesics, intravenous (IV) for multivitamins, oral for albendazole (Leeford Healthcare Itd, India, 1 tab) and subcutaneous(S/C) for ivomec (A menarini India Pvt Ltd, India, $0.5 \mathrm{ml}$ ). For $\mathrm{I} / \mathrm{M}$, the injection was given within the muscles of the leg (Biceps femoris). For intravenously, the injection was administered directly into the veins of the arm (cephalic vein). For oral administration, the albendazole (Leeford Healthcare Itd, India, $1 \mathrm{tab}$ ) was diluted with 10 $\mathrm{ml}$ of distilled/sterile water and then inserted into the mouth using $10 \mathrm{ml}$ syringe. For subcutaneous, the injection was given under the skin. Superficially, the eye ointment was applied on the outer layer of the eye. Most of the animals recovered after three days of treatment. The signs/symptoms of various diseases and the diagnosis, mode of treatment and method of administration were recorded in the result section.

\section{RESULTS}

During the visit to the veterinary hospital, the various kinds of animal diseases and their corresponding treatments were observed; which were ectoparasitic diseases e.g mange, endoparasitic diseases e.g. diarrhea, mammary gland diseases e.g mastitis, reproductive disease e.g. dystocia. The modern drugs used in the study to treat the ruminant diseases include albendazole (Leeford Health care Itd, India) 1 tab and ivecmectin (Merck sharp anddohme pty Itd, Australia) 1 tab for endoparasitic diseases, antibiotics e.g pen strep (Dutch Farm International BV, Holland) $3 \mathrm{ml}$, oxylet (Kachhela medex private limited, India) $1 \mathrm{ml}$, multivitamin such as Emvit (unimed,India) $2 \mathrm{ml}$, vitaflash (kepro,Netherlands) $2 \mathrm{ml}$, B/complex (Estrellas life sciences private limited, India) 0.5 $\mathrm{ml}$ and analgesic e.g salphen (Industrial corporation of India) $1 \mathrm{ml}$ and so on (Table 1).

\section{DISCUSSION}

Modern methods of treating ruminant diseases provide some higher ingredient that are lacking in traditional method, which provides the reason for integration of the two methods for sustainable health management system and to eliminates anthelmintic resistance caused by modern drugs (Shalaby, 2013). More so, modern methods are needed in some certain situations e.g. abortion and uterine prolapsed, mastitis, swellings on the body to prevent infections of the animal. Tetanus can be treated using both modern method and traditional method (Thwaites and Loan, 2015).

Anti-parasitic drugs such as ivomec (A menarini India Pvt Ltd, India, $0.5 \mathrm{ml}$ ) and albendazole (Leeford Health care Itd, $1 \mathrm{tab}$ ) were used to treat the mange and diarrhea in the study area, which agrees with the study of Basheir et al. (2012) and Nalule et al. (2011). Albendadole (Leeford Healthcare Itd, India,1 tab) was used to treat nematodes causing diarrhea. Diarrhea occurred when the ruminants feed on the contaminated food and it was caused by Trichostrongylus sp. Antibiotics such as $3 \mathrm{ml}$ of penstrep (Dutch Farm International BV) and $1.5 \mathrm{ml}$ of oxylet were used to kill any microorganism that wants to cause diseases such as foot rot (Sagliyan et al., 2008). Some of the diseases treated using antibiotics include mastitis (Pieterse and Todorov, 2010), uterine prolapse, tetanus, arthritis and so on (Table 1). Mastitis is an inflammation of the mammary gland which was caused by a bacterial infection. The bacteria that mostly caused mastitis in ruminants are Staphylococcus aureus and Pasteurella hemolytica. Mastitis was usually treated with intramammary infusions of antibiotics, systemic antibiotics as in (Pieterse and Todorov, 2010), and anti inflammatory drugs (Aspirin). Uterine prolapse is when the womb (uterus) is turned inside out and pushed through the birth 
Table 1. Common parasitic diseases in Ekiti State and modern methods of treatment.

\begin{tabular}{|c|c|c|c|}
\hline Signs/symptoms & Diagnosis & Treatment & $\begin{array}{l}\text { Route of } \\
\text { administration }\end{array}$ \\
\hline $\begin{array}{l}\text { Ectoparasitic diseases (Mange) } \\
\text { Rashes over the body } \\
\text { Whitish substance around the body } \\
\text { Emaciation, weakness and depression of } \\
\text { the body }\end{array}$ & Mange & $\begin{array}{l}0.5 \mathrm{ml} \text { ivomec } \\
2 \mathrm{ml} \text { vitalflash } \\
1 \mathrm{ml} \text { oxylet } \\
1 \mathrm{ml} \text { of } \mathrm{B} / \mathrm{complex}\end{array}$ & $\begin{array}{l}\text { Subcutaneous (so as } \\
\text { to have direct impact } \\
\text { on the parasite on the } \\
\text { skin }\end{array}$ \\
\hline $\begin{array}{l}\text { Endoparasitic diseases (diarrhoea) } \\
\text { Anorexia (lack of appetite) } \\
\text { dyspnoea (respiratory disease) difficulty in } \\
\text { breathing } \\
\text { Diarrhoea (persistent stooling) }\end{array}$ & Kata & $\begin{array}{l}0.5 \mathrm{ml} \mathrm{B} \text { complex } \\
0.5 \mathrm{ml} \text { oxylet } \\
10 \mathrm{ml} \text { mixture of } 1 \text { tab Thalazole }+1 \\
\text { tab Albendazole }\end{array}$ & $\begin{array}{l}\mathrm{I} / \mathrm{M} \\
\text { Oral administration }\end{array}$ \\
\hline $\begin{array}{l}\text { Microbial disease Mammary gland disease } \\
\text { Abscess at the breast containing pus } \\
\text {-Lack of appetite } \\
\text {-Painful breast }\end{array}$ & Mastitis & $\begin{array}{l}2 \mathrm{ml} / 20 \mathrm{~kg} \text { antibiotics to kill the } \\
\text { germs at the breast } \\
\text { B/complex to increase the appettite } \\
\text { Analgesic to relieve the pain } \\
\text { Syringe was put inside the abscess } \\
\text { To remove the pus and then treat it }\end{array}$ & $\mathrm{I} / \mathrm{M}$ \\
\hline $\begin{array}{l}\text { Crusty whitish growth on the udder and } \\
\text { swollen on the body }\end{array}$ & $\begin{array}{l}\text { Mastitis (Multiple } \\
\text { abscess) }\end{array}$ & $\begin{array}{l}1 \mathrm{ml} \text { ivomec } \\
3 \mathrm{ml} \text { penstrep } \\
2 \mathrm{ml} \text { Emvit }\end{array}$ & $\begin{array}{l}\mathrm{S} / \mathrm{C} \\
\mathrm{I} / \mathrm{M}\end{array}$ \\
\hline Reproductive disease Uterus came out & Uterus prolapsed & $\begin{array}{l}\text { The uterus is pushed inside and } \\
\text { the vulva is sutured to remain small } \\
\text { hole for excreting } \\
\text { Antibiotics is given to prevent } \\
\text { infection } \\
\text { Analgesic is given to relieve pain } \\
\text { B-complex }\end{array}$ & $\mathrm{I} / \mathrm{M}$ \\
\hline $\begin{array}{l}\text { Greenish fluid from the vulva } \\
\text {-straining (folding up) } \\
\text {-lack of appetite } \\
\text {-complaint about crying/ shouting for } 3 \text { days } \\
\text {-posterior area matted with dried discharges } \\
\text {-dripping bloody discharge from the vulva } \\
\text {-blinking like crying for her kid }\end{array}$ & Abortion & $\begin{array}{l}\text { Uterus was washed with } \mathrm{KMNO}_{4} \text { to } \\
\text { disinfect the uterus } \\
2 \mathrm{ml} / 10 \mathrm{~kg} \text { given antibiotics to kill the } \\
\text { germ } \\
\text { Analgesic to relieve the pain } \\
\text { B complex to increase the appetitte } \\
1.5 \mathrm{ml} \text { Penstrep } \\
1.5 \mathrm{ml} \text { Vitaflash } \\
1 \mathrm{ml} \text { salphen }\end{array}$ & $\mathrm{I} / \mathrm{M}$ \\
\hline $\begin{array}{l}\text { Has been in labour for } 3 \text { days without a } \\
\text { success of delivery }\end{array}$ & Dystocia & $\begin{array}{l}\text { Left flanked, shaved, washed, } \\
\text { cleaned and the animal was } \\
\text { operated under left arm } \\
\text { Two live kids delivered and incision } \\
\text { line closed using braided silk } \\
2 \mathrm{ml} \text { Penstrep } \\
1 \mathrm{ml} \text { oxytocin } \\
1 \mathrm{ml} \text { vitamin } \mathrm{k} \\
2 \mathrm{ml} \text { Pcm } \\
2 \mathrm{ml} \mathrm{B/complex}\end{array}$ & $\mathrm{I} / \mathrm{M}$ \\
\hline $\begin{array}{l}\text { Inflammed vulva, rough hair coat, inflamed } \\
\text { right hind leg and interdigital space and } \\
\text { kidded } 2 \text { wks ago }\end{array}$ & $\begin{array}{l}\text { Vulvitis } \\
\text { Foot rot } \\
\text { Helminthiasis }\end{array}$ & $\begin{array}{l}0.5 \mathrm{ml} \text { ivomec } \\
2 \mathrm{ml} \text { Penstrep } \\
2 \mathrm{ml} \mathrm{pcm} \mathrm{(salphen)} \\
2 \mathrm{ml} \mathrm{B} \mathrm{complex}\end{array}$ & $\begin{array}{l}\mathrm{S} / \mathrm{C} \\
\mathrm{I} / \mathrm{M}\end{array}$ \\
\hline $\begin{array}{l}\text { 5. other microbial diseases foaming from the } \\
\text { mouth, fowl odour mouth oral/nasal } \\
\text { discharge }\end{array}$ & PPR & $\begin{array}{l}\text { Mouth washed with } \mathrm{KMNO}_{4} \\
\text { solution, flaggy }+ \text { Thalazole+ } \\
\text { Albendazole tab } \\
2 \mathrm{ml} \text { oxylet } \\
2 \mathrm{ml} \text { sulpha } \\
2 \mathrm{ml} \text { Emvit }\end{array}$ & $\begin{array}{l}\mathrm{O} \\
\mathrm{I} / \mathrm{M}\end{array}$ \\
\hline $\begin{array}{l}\text { Profuse diarrhea, anorexia, occulo nasal } \\
\text { discharge and anaemia with starring hair } \\
\text { coat and pregnant }\end{array}$ & Kata & $\begin{array}{l}\text { Dewormed with albendazle } \\
2 \mathrm{ml} \text { emvit } \\
2 \mathrm{ml} \text { sulpha } \\
2 \mathrm{ml} \text { iron dextrane }\end{array}$ & $\begin{array}{l}\mathrm{O} \\
\mathrm{I} / \mathrm{M} \\
\mathrm{I} / \mathrm{M} \\
\mathrm{I} / \mathrm{M}\end{array}$ \\
\hline
\end{tabular}


Table 1. Contd.

\begin{tabular}{|c|c|c|c|}
\hline $\begin{array}{l}\text { Loss of appetite with nasal discharge } \\
\text { Coughing }\end{array}$ & Helminthiasis/PPR & $\begin{array}{l}\text { Albendazole bolus } \\
0.5 \mathrm{ml} \text { ivomec } \\
1.5 \mathrm{ml} \text { oxylet } \\
1.5 \mathrm{ml} \text { Emvit } \\
\end{array}$ & $\begin{array}{l}\mathrm{O} \\
\mathrm{l} / \mathrm{M} \\
\mathrm{l} / \mathrm{M} \\
\mathrm{l} / \mathrm{M}\end{array}$ \\
\hline $\begin{array}{l}\text { Hit on the right fore limb, swollen shoulder } \\
\text { joint encrustation on muzzle }\end{array}$ & Trauma and PPR & $\begin{array}{l}0.5 \mathrm{ml} \text { Oxylet } \\
1 \mathrm{ml} \text { vitaflash } \\
\text { Albendazole } \\
1 \mathrm{ml} \text { salphen } \\
\end{array}$ & $\begin{array}{l}\mathrm{I} / \mathrm{M} \\
\mathrm{O}\end{array}$ \\
\hline $\begin{array}{l}\text { Observed extended left abdominal region } \\
\text { with dyspnoea and dialated nostrils }\end{array}$ & Tetanus & $\begin{array}{l}2 \mathrm{ml} \text { of Penstrep } \\
\text { B/complex } \\
\text { To be given liquid paraffin }\end{array}$ & $\begin{array}{l}\mathrm{I} / \mathrm{M} \\
\mathrm{O}\end{array}$ \\
\hline (Pain disease) Not able to stand & Arthritis & $\begin{array}{l}0.4 \mathrm{ml} \text { Penstrep } \\
0.4 \mathrm{ml} \text { salphen } \\
0.4 \mathrm{ml} \text { Emvit }\end{array}$ & $\mathrm{I} / \mathrm{M}$ \\
\hline $\begin{array}{l}\text { (Microbial disease) Crusty whitish growth on } \\
\text { the lip }\end{array}$ & Orf & $\begin{array}{l}\text { Lesion removed cleaned and } \\
\text { dressed } \\
0.4 \mathrm{ml} \text { Penstrep }\end{array}$ & $\mathrm{I} / \mathrm{M}$ \\
\hline $\begin{array}{l}\text { Foaming from the mouth for } 3 \text { days with } \\
\text { watery feaces }\end{array}$ & Helminthiasis & $\begin{array}{l}\text { Atropine } \\
1.5 \mathrm{ml} \text { Oxylet } \\
1.5 \mathrm{ml} \text { Emvit }\end{array}$ & $\mathrm{I} / \mathrm{M}$ \\
\hline $\begin{array}{l}\text { Reproductive diseases Penis protrude } \\
\text { outside with swollen testes owner request } \\
\text { for castration }\end{array}$ & Paraphimosis & $\begin{array}{l}\text { Penis replace and sutured } 1.5 \mathrm{ml} \\
\text { penstrep } \\
1.5 \mathrm{ml} \text { salphen } \\
2 \mathrm{ml} \text { Emvit } \\
\end{array}$ & $\mathrm{I} / \mathrm{M}$ \\
\hline Foot swollen and ulcerated & Foot rot & $\begin{array}{l}\text { Wound debridement dressing } \\
1 \mathrm{ml} \text { Penstrep } \\
2 \mathrm{ml} \text { salphen } \\
3 \mathrm{ml} \text { vitaflash } \\
\end{array}$ & $\mathrm{I} / \mathrm{M}$ \\
\hline $\begin{array}{l}\text { Swollen abdomen after castration Pensile } \\
\text { blockage }\end{array}$ & Penile trauma & $\begin{array}{l}1.5 \mathrm{ml} \text { salphen } \\
1.5 \mathrm{ml} \text { Oxylet } \\
1.5 \mathrm{ml} \text { Emvit }\end{array}$ & $\mathrm{I} / \mathrm{M}$ \\
\hline $\begin{array}{l}\text { Swollen left abdomen, profuse Watery } \\
\text { diarrhoea, worm in faeces }\end{array}$ & $\begin{array}{l}\text { Hermia tapeworm } \\
\text { Infestation }\end{array}$ & $\begin{array}{l}\text { Tab Alb ivermectin } \\
3 \mathrm{ml} \text { sulphane } \\
2 \mathrm{ml} \text { vitaflash }\end{array}$ & $\mathrm{I} / \mathrm{M}$ \\
\hline $\begin{array}{l}\text { Oculo-nasal discharges with corned opticity } \\
\text { and reddened conjunctivae }\end{array}$ & Conjuctivitis & $\begin{array}{l}\text { Eye ointment applied instructed to } \\
\text { apply } 2 x \text { daily } 0.5 \mathrm{ml} \text { oxylet }\end{array}$ & $\mathrm{I} / \mathrm{M}$ \\
\hline Off feed, swollen neck, $\mathrm{T} 40-24^{\circ} \mathrm{C}$ fleas & $\begin{array}{l}\text { Fleas infestation, } \\
\text { trauma PPR }\end{array}$ & $\begin{array}{l}0.5 \mathrm{ml} \text { Emvit } \\
0.5 \mathrm{ml} \text { ivomec } \\
2 \mathrm{ml} \text { salphen } \\
1.5 \mathrm{ml} \text { oxylet }\end{array}$ & $\mathrm{S} / \mathrm{C}$ \\
\hline Wound on the left front limb & Wound & $\begin{array}{l}\text { 1.5ml Oxylet } \\
\text { Wound shaved, cleaned and } \\
\text { dressed } \\
3 \mathrm{ml} \text { Penstrep } \\
2 \mathrm{ml} \text { Emvit } \\
2 \mathrm{ml} \text { Salphen } \\
\text { Tetanus required to be given }\end{array}$ & $\mathrm{I} / \mathrm{M}$ \\
\hline
\end{tabular}

$\mathrm{I} / \mathrm{M}=$ Intramuscular, $\mathrm{O}=$ Oral, $\mathrm{S} / \mathrm{C}=$ Subcutaneous.

Source: Veterinary Hospital Ado Ekiti.

canal by abdominal straining in ruminants (Bello et al., 2013), which also occurred in this study. Affected ruminants were given antibiotics and oxytocin. Tetanus is caused by Clostridium tetani and it can be treated using antiserum and antibiotics. Arthritis is an inflammation of the junctions of the legs resulting in reduction of production, carcass value and death. It is caused by bacteria e.g Erys/pelothix rhusiopathiae and can be treated using massive doses of antibiotics. The use of multivitamins such as $1 \mathrm{ml}$ of vitaflash (Kepro, Netherlands), $2 \mathrm{ml}$ of Emvit (Uni-med, India) and $0.5 \mathrm{ml} \mathrm{B}$ complex (Estrellas life sciences private limited, India) were to build/boost the immunity of the animal to prevent attack from any foreign organism. The use of analgesic such as $1 \mathrm{ml}$ of salphen (Industrial corporation of India, India) was to relieve the animal from any pain. Drugs that can be used 
in the treatment of pain include opoids (Morphine), non steroidal anti-inflammatory drugs (Aspirin), a2adrenoreptor agonists and local anaesthetics (ketamine). Different types of drugs have their analgesic effects in different ways. There can be combination of both traditional and modern drug in treating disease such as tetanus, in other avoid the resistance resulting from the use of modern drugs alone (Shalaby, 2013).

\section{Conclusion}

Different methods of treating ruminant diseases can help reduce the rate of diseases outbreak thereby improving the economy of the ruminant farmers and that of Ekiti state at large. It is therefore recommended that extension workers should disseminate the findings in this study to rural dwellers for effecting treatment of ruminant diseases in the study area.

\section{CONFLICT OF INTEREST}

The authors declare that they have no conflict of interest.

\section{ACKNOWLEDGEMENT}

We thank Dr Adeniyi and Mr Ogundaisi at the veterinary hospital in Ado Ekiti, for their help and assistance during the collection of the data from the hospital.

\section{REFERENCES}

Adedeji, O. S., \& Aiyedun, J. O. (2013). Ethnoveterinary practices in the treatment of skin disease (Mange) in small ruminants in Kwara State, Nigeria. Journal of Environmental Issues and Agriculture in Developing Countries, 5(1), 51-55.
Al-Assaf, A. (2012). Economic implications of small ruminant diseases in the Northern area of Jordan. Journal of Food, Agriculture and Environment, 10(1), 323-326.

Basheir, B. O., EIMalik, K. H., Abdelgadir, A. E., \& Gameel, A. A. R. (2012). Traditional and modern practices in the diagnosis, treatment and prevention of animal diseases in South Kordofan State, Sudan. Journal of Cell and Animal Biology, 6(15), 213-225.

Bello, A., Umaru, M. A., Alkali, B. R., Dalhatu, M., \& Mahmud, M. A. (2013). Vaginal and uterine prolapse in a 3-year old ouda ewe in Sokoto, Nigeria. Health, Safety and Environment, 1(2), 61-63.

Mafimisebi, T. E., Oguntade, A. E., Fajemisin, A. N., \& Aiyelari, O. P. (2012). Local knowledge and socio-economic determinants of traditional medicines' utilization in livestock health management in Southwest Nigeria. Journal of ethnobiology and ethnomedicine, 8, Article number 2.

Nalule, A. S., Karue, C. N., \& Katunguka-Rwakishaya, E. (2011). Anthelmintic activity of Phytolacca dodecandra and Vernonia amygdalina leaf extracts in naturally infected small East African goats. Livestock Research for Rural Development, 23(12), 54-66.

Pieterse, R., \& Todorov, S. D. (2010). Bacteriocins: exploring alternatives to antibiotics in mastitis treatment. Brazilian Journal of Microbiology, 41(3), 542-562.

Sagliyan, A., Gunay, C., \& Han, M. C. (2008). Comparison of the effects of oxytetracycline and penicillin-streptomycin in the treatment of footrot in sheep. Journal of Animal and Veterinary Advances, 7(8), 986-990.

Shalaby, H. A. (2013). Anthelmintics resistance; how to overcome it? Iranian journal of parasitology, 8(1), 18-32.

Thwaites, C. L., \& Loan, H. T. (2015). Eradication of tetanus. British Medical Bulletin, 116(1), 69-77.

Wendy J., Underwood., Blauwiekel, R, Delano, M., Gillesh, R., Mischler, S., \& Schoell, A. (2015). Biology and diseases of ruminants (Sheep, goats and cattle). Laboratory Animal Medicine, Pp. 623-694.

Yuan, H., Ma, Q., Ye, L., \& Piao, G. (2016). The traditional medicine and modern medicine from natural products. Molecules, 21(5), 559 